УдК 340.5

DOI https://doi.org/10.32837/pyuv.v1i3(28).314

\author{
B. О. Карпічков \\ кандидат юридичних наук, \\ асистент кафедри історії права та держави \\ Київського національного університету імені Тараса Шевченка
}

\title{
ЕВОЛЮЦІЯ ЮРИДИЧНОЇ КОМПАРАТИВІСТИКИ В УКРАЇНІ
}

Світові глобалізаційні процеси вимагають більш глибинного осмислення, зокрема, з позиції юридичної компаративістики, що покликана сформувати належне уявлення про правову дійсність зарубіжних країн, а також перейняти їх позитивний правовий досвід.

Однак, попри важливість компаративістики та чисельні порівняльно-правові дослідження, серед вітчизняних науковців немає єдиної точки зору з приводу моменту зародження цієї науки в Україні, а наявні періодизації є виключно авторським поглядом на дану проблему і відображають лише окремі сторінки історії.

Метою публікації є комплексне дослідження процесу еволюції компаративістики як самостійної юридичної науки на теренах Української Держави в різні періоди її розвитку на основі аналізу праць вітчизняних компаративістів. Основним завданням дослідження є виокремлення періодів становлення української компаративістики, а також факторів, що вплинули на її розвиток і сприяли виокремленню порівняльного правознавства у самостійну галузь знань.

Дослідженням проблем юридичної компаративістики у різні роки займались такі відомі українські вчені: М.Д. Іванішев, М.Ф. Владимирський-Буданов, Ф.І. Леонтович, М.П. Загоскін, К.О. Неволін, О.В. Романович-Славатинський, С.М. Орнатський, М.К. Ренненкампф, Б.А. Кістяківський, А.М. Максимейко, М.М. Ковалевський, С.Є. Десницький, Ф.В. Тарановський, М.С. Грушевський, В.М. Корецький, С.О Макогон, П.Ф. Мартиненко, Р.Ю. Синельникова, Г.В. Александренко, О.І. Ганусець, Я.Г. Плясун, В.Ф. Пеньківський, В.М. Шаповал, В.Н. Денисов, Г.І. Чангулі, Ю.І. Нипорок, В.М. Селіванов, В.К. Забігайло, О.Є. Лисенко, В.П. Мартиненко, М.I. Марченко, В.В. Оксамитний, В.П. Казимирчук, О.В. Зайчук, Л.О. Корчевна, Л.А. Луць, Н.М. Оніщенко, П.М. Рабінович, О.Ф. Скакун, О.О. Мережко, В.В. Молдован, М.М. Страхов, Ю.М. Оборотов, Х.Н. Бехруз, О.В. Кресін, Н.Р. Малишева, Ю.Ю. Леонов, B.I. Євінтов, О.В. Зайчук, В.С. Журавський, О.Л. Копиленко, Ю.В. Цвєткова та інші.

Вітчизняна компаративістика пройшла складний і тривалий шлях розвитку від методу юридичної науки до самостійної галузі знань. 3 приводу моменту зародження компаративістики в Україні існують дві протилежні точки зору. Одні вчені вважають, що порівняльне правознавство з'явилося лише наприкінці XVIII ст. [23, с. 75-79], однак, на нашу думку, більш переконливою $є$ інша точка зору, згідно з якою порівняльне правознавство має настільки ж давню історію, як і саме українське право [19, с. 12].

Витоки порівняльно-правових ідей беруть свій початок у далекому Х ст. у Русі. Так, перші спроби дослідження і порівняння норм іноземного права можна зустріти у договорах Русі з Візантією, за якими сторони для врегулювання міждержавних відносин використовували не власне, а запозичене право, тобто право іншої сторони, або ж взагалі застосовували спеціально створені норми на основі порівняння права Русі та Візантії [28, с. 4].

Важливе значення для розвитку порівняльно-правових ідей у Русі мала рецепція права. 3 прийняттям християнства сформувалася нова система церковного права на основі запозичення давньоруською державою норм 3 римських, юдейських, візантійських і болгарських правових джерел [33, с. 10]. Реципійоване візантійське право поглибило й збагатило національне право Русі та вплинуло на подальший розвиток законодавства княжої доби [34, с. 45]. Слід підкреслити, що рецепція візантійського права не являла собою просту компіляцію норм, а була переробкою права Візантії відповідно до права та звичаїв Русі шляхом їх порівняння. Рецепція візантійського права відобразилась у Церковних Уставах Володимиpa (X-XII ст.) і Ярослава Мудрого (XII-XIII ст.), «Слові про закон і благодать» (XI ст.) київського митрополита Іларіона, а також «Руській Правді» (XI-XII ст.), де органічно поєднались давньоруські звичаї, державне право та реципійоване візантійське право. Поширення «Номоканонів» $\mathrm{i}$ збірників візантійського права «Еклоги» i «Прохирону» відбулося лише після прийняття Просторової редакції "Руської правди» на початку XIII ст. [26, с. 37].

Нестор Літописець у «Повісті минулих літ» (XI-XII ст.) зазначав, що «кожен народ має писаний закон, або ж звичай, якого люди, які не знають закону писаного, дотримуються як припису отців» $[19$, с. 34$]$. Загалом літопис у формі переказів, оповідань та легенд описував історію слов'ян- 
ського народу, події хрещення на Русі, а також порівнював устрій різних слов'янських племен, вказуючи на відмінності між ними, тому «Повість минулих літ» можна сміливо вважати одним із перших вітчизняних порівняльних досліджень.

За Литовсько-Руської доби (друга половина XIII - друга половина XVI ст.) відбулася рецепція західноєвропейського феодального права, тому порівнянню в цей період підлягало західноєвропейське і давньоруське право. Важливим наслідком досліджень та адаптації західноєвропейського середньовічного права стала поява у XIV ст. в українських містах німецького права, яке отримало назву магдебурзького. Також при створені Литовських Статутів комісією були досліджені і порівняні норми римського, руського, польського та німецького звичаєвого права. Третій Литовський Статут (1588 р.) виявився настільки вдалим, що його положення зберігали чинність на українських землях аж до середини XIX століття.

У XVIII ст. порівняльне правознавство використовувалось як практична діяльність з порівняння правових норм на наднаціональному та регіональному рівнях. Прагнення держави до систематизації й вдосконалення українського права сприяли розвитку порівняльно-правових досліджень. Для систематизації норм українського права залучались спеціально створені комісії, а також приватні кодифікатори. Найвідомішими збірниками права того часу були «Соборне уложення» (1649 р.), «Рішительні пункти» (1728р.), «Процес короткий, приказний...» (1734 р.), «Права, за якими судиться малоросійськи народ" (1743 р.), «Суд і расправа в правах малороссийских...» (1750-1758 рр.) та інші. Більшість збірників створювалась на основі порівняння положень Литовського Статуту, магдебурзького i хелмінського права, гетьманського та російського законодавства, судової і адміністративної практики, українського звичаєвого права, що вказує на високий рівень тогочасної вітчизняної юридичної науки [36, с. 30].

3 початком XIX ст. розпочався новий етап вітчизняної компаративістики. Ідеологія Російської імперії, яка відобразилась не лише в політиці, а й у сфері вищої освіти, сприяла розвитку тільки історичної школи права. Згідно зі «Статутом університетів Російської імперії» 1804 р. передбачалося утворення в університетах кафедр «права найвидатніших як давніх, так і нових народів» [27, с. 10] на яких мав читатись курс історії та сучасного стану права зарубіжних країн [4, с. 89].

Важливою історичною подією стало відкриття у 1834 році в Київському університеті юридичного факультету, на якому значна увага приділялась порівняльним дослідженням права України, Росії та інших слов'янських держав. На юридичному факультеті Київського університету сформували- ся унікальні на той час історико-юридична школа, школа романістики і школа міжнародного права [5, с. 14]. Провідна роль у розвитку порівняльно-правових ідей належала київській історичній школі права, засновниками якої були М.Д. Іванішев та його учні М.Ф. Владимирський-Буданов і Ф.І. Леонтович. До представників школи також належали Г.В. Демченко, О.О. Малиновський, М.П. Загоскін, М.О. Максимейко, О.М. Філіппов, М.М. Ясинський, О.Я. Тарановський і Ф.В. Тарановський [1, с. 25].

Одним з перших, хто почав використовувати порівняльно-правовий метод у своїх дослідженнях, став професор Київського університету М.Д. Іванішев. Вчений намагався виокремити у праві слов' янських народів спільне етнічне коріння, яке відрізняє їх відінших народів [2, с. 33, 111]. Його праця «Про плату за вбивство в давньому російському й інших слов'янських законодавствах у порівнянні з германською вирою» (1840р.) стала першим монографічним порівняльно-правовим дослідженням в Російській імперії [32, с. 29-30]. Основною метою своїх досліджень М.Д. Іванішев вважав пізнання загальнослов'янської правової культури, а на основі їі «чистоти» він хотів заповнити прогалини в історії права кожного з цих народів за принципом аналогії [9, с. 111-112]. На думку вченого, щоб виокремити відмінні риси у праві різних народів, спочатку необхідно виокремити спільні риси у праві подібних народів. Порівнюючи більш пізні пам' ятки права слов'янських народів з більш ранніми пам'ятками німецького народу, науковець дійшов висновку про досконалість слов'янського права порівняно з німецьким [9, с. 2].

Послідовник історико-юридичної школи Ф.І. Леонтович вважав, що сутність історико-порівняльного методу полягає у розкритті подібності в однорідних правових інститутах різних народів [20, с. 116]. На його думку, дослідження історії права слов'янських народів має важливе наукове значення через його схожість 3 давньоруським правом. Коло наукових пошуків Ф.І. Леонтовича охоплювало дослідження «Руської Правди», «Полицького Статуту», пам'яток південно-західних слов'ян, хорвато-далматського законодавства, порівняння права Руської та Литовсько-Руської доби, вивчення аналогій між монгольським і московським адміністративно-правовим устроєм, дослідження звичаєвого права народів Північного та Східного Кавказу тощо [21, с. 366-371].

Ідеї порівняльного правознавства розвивав відомий український науковець М.Ф. Владимирський-Буданов, який теж наголошував на подібності права всіх слов' янських народів. Вчений вказував на наявність самостійних рис у розвитку права кожного з цих народів, звертаючи увагу на можливість рецепції окремих елементів 
права між ними, та засуджував рецепцію права неслов' янських народів [16, с. 31]. М.Ф. Владимирський-Буданов засуджував погляди деяких представників історичної школи права щодо відновлення «чистоти» національного права, вважаючи, що право з часом має еволюціонувати як на національному, так і на всесвітньому рівні [31, с. 47-48].

З 1839 року на юридичному факультеті Київського університету почала викладатися дисципліна «Історія руського права». Ініціатором викладання цієї дисципліни став відомий на той час в Російській імперії та за її межами історик і теоретик права, професор К.О. Неволін. У 1842 році на кафедрі енциклопедії законознавства, яку він очолював, було створено сектор енциклопедії законодавства та сектор історії законодавства, які мали сприяти популяризації історичних досліджень права слов'янських народів. Вже з 1863 року на юридичному факультеті Київського університету функціонували кафедра історії російського права, кафедра історії слов'янських законодавств і кафедра історії найважливіших іноземних законодавств стародавніх і нових. На кафедрі римського права продовжував діяти обов'язковий курс історії римського права [11, с. 77].

Завдяки порівняльно-правовим дослідженням історичної школи права вдалось реконструювати державотворчі та правотворчі процеси, що відбувались на українських землях впродовж тривалих історичних періодів. Багато наукових праць представників історичної школи присвячено дослідженню особливостей державно-правового ладу Київської, Волинської і Подільської земель, де в межах концепції західноруського права вченими висвітлювалася низка проблем українського національного права. Важливим здобутком київської історичної школи права можна вважати розробку періодизації Литовсько-Руської держави та її правову характеристику [2, с. 23]. Дослідження представників київської історичної школи права заклали основу для подальших наукових пошуків українських компаративістів.

Одним з перших, хто дослідив історію становлення порівняльного правознавства, був український компаративіст М.К. Ренненкампф. У своїй статті «Про сучасну обробку порівняльного правознавства» (1869р.) вчений зазначив, що порівняльно-правова методологія XVII - початку XIX ст. втратила свій науковий авторитет. M.К. Ренненкампф вважав, що науковці минулого порівнювали право різних часів і народів, однак самої науки порівняльного правознавства тоді ще не могло існувати, адже не було відповідної методологічної бази, тому всі порівняльно-правові дослідження тих часів були безсистемними. На думку вченого, порівняльне правознавство стало науковим лише у 20-х роках XIX ст., що було пов'язано з розвитком науки і суперечкою історичної та філософської шкіл права [30, с. 90-96].

Наприкінці XIX - початку XX ст. порівняльно-правові традиції продовжували українські вчені М.М. Ковалевський, Б.А. Кістяківський, A.М. Максимейко, М.М. Ковалевський та С.Є. Десницький [23, с. 86]. У своїх дослідженнях М.M. Ковалевський активно використовував історико-порівняльний метод. У праці «О методологических приемах при изучении раннего периода в истории учреждений» (1878р.) науковець підкреслював, що використання історико-порівняльного методу є єдиним правильним шляхом для дослідника у пізнані права інших народів. Прийомам дослідження історичних пам'яток права М.М. Ковалевський також присвятив окрему главу в роботі «Историко-сравнительный метод в юриспруденции и приемы изучения истории права» (1880 р.). Однією із найвідоміших праць науковця є «Происхождение современной демократии» (1895р.) [14, с. 22-25]. М.М. Ковалевський вважав, що подібність правових інститутів різних народів визначається подібністю умов їхнього історичного розвитку, а запозичення правових інститутів одним народом в іншого є прямим шляхом до розвитку права. Однак запозичення права у чистому вигляді не може існувати, оскільки кожний народ додає до нього свої особливості, в результаті чого створюється нове право [15, с. 51-52].

На початку XX ст. постало питання про інституціоналізацію порівняльно-правових досліджень. Так, у «Записці про відділ соціальних наук» від 4 вересня 1918 р. на базі Української академії наук пропонувалося створити кафедру слов'янського законодавства, метою якої було б заповнити прогалини у відповідних правових знаннях та стати «посередницею між кафедрами порівняльної історії права та права західноруського й українського» [12, с. 139-140.].

14 листопада 1918 року у III відділі УАН було створено кафедру порівняльної історії права на чолі 3 відомим українським науковцем, академіком Ф.В. Тарановським, автором «Підручника-енциклопедії права» (1917 р.) [12, с. 201-205]. Передбачалось, що порівняльно-правові дослідження у III відділі УАН мали здійснюватися комісією звичаєвого права України і комісією західноруського та українського права. Однак порівняльним дослідженням права співробітники комісій уваги майже не приділяли, а на початку 1920 року після еміграції Тарановського з УСРР кафедра порівняльної історії права взагалі припинила своє існування.

Аналогічна доля спіткала ініціативу М.С. Грушевського щодо розробки науково-дослідною кафедрою історії України Всеукраїнської академії наук у 1927-1928 рр. теми «Історія України в зв'язку з загальною історією культури і соці- 
ального розвитку» i підготовки першого нарису історії України у порівняльній перспективі [34, c. 167].

У 20-х роках XX ст. розвиток порівняльного правознавства в Україні був суттєво обмежений умовами ідеологічного диктату і політикою самоізоляції, відсутністю кваліфікованих юридичних кадрів, а також хибністю методологічних поглядів деяких науковців з приводу недоцільності порівняння буржуазного та соціалістичного права. Радянська ідеологія стала основою для формування всього соціалістичного права, а розходження з буржуазними ідеями і негативним ставленням комуністичної партії до іноземного права змусило українських компаративістів відійти від класичного порівняння права зарубіжних країн. Через це більшість порівняльно-правових досліджень того часу була замінена лише на критику буржуазного права [7, с. 262]. У цей період серед науковців розгорнулася суперечка з приводу розуміння порівняльного правознавства як самостійної галузі знань або як одного з методів юридичної науки. Після закінчення Першої світової війни та Жовтневої революції 1917 р. в Росії під порівняльним правознавством починають розуміти порівняльний метод, основним завданням якого є класифікація об’єктів іноземного права [7, с. 262-263].

Центральне місце в предметі порівняльного правознавства посідало соціалістичне право та деякі релігійні правові системи світу. Повноцінному порівнянню піддавалося лише право СРСР та інших соціалістичних держав [7, с. 267-269]. Курси порівняльного правознавства були виключені з програм вищих закладів освіти, і тільки у 1936 році було введено курс загальної історії держави і права для студентів-юристів [6, с. 48; 8, с. 179]. Проблеми порівняльно-правових пошуків того часу були звужені до вивчення соціалістичного права. Дослідження права зарубіжних країн, історії права та юридичної методології взагалі були призупинені, а поодинокі порівняльно-правові дослідження були здебільшого результатом особистої ініціативи викладачів юридичних факультетів [4, с. 47].

У 1944 році в Київському університеті імені Тараса Шевченка був заснований факультет міжнародних відносин, де велась підготовка висококваліфікованих кадрів для Міністерства закордонних справ УРСР.

У 1949 році при Академії наук УРСР був створений Сектор держави і права на чолі з В.М. Корецьким, в якому велись дослідження права країн народної демократії [13, с. 7].

Своєрідним каталізатором для розвитку порівняльного правознавства стало проголошення у 1960-х роках ідеї мирного співіснування соціалістичної та капіталістичної світових систем [25, с. 226-227]. Розвитку порівняльно-право- вих ідей сприяло посилення співробітництва між СРСР та іноземними країнами, а також формування світової соціалістичної правової сім’ї й розширення кола нових постколоніальних держав, що більшою чи меншою мірою потрапили до сфери впливу СРСР [29, с. 5]. Унаслідок цього виникла досить практична потреба у порівняльному дослідженні зарубіжного права [17, с. 78].

У 1962 році в Київському університеті імені Тараса Шевченка була створена кафедра міжнародного права та зарубіжного законодавства, а в Інституті міжнародних відносин Київського університету - кафедра порівняльного правознавства. У Київському університеті велась розробка підручників і посібників з права зарубіжних країн С.О Макогоном, П.Ф. Мартиненком, P.Ю. Синельниковою. Український компаративіст П.Ф. Мартиненко у 1980 році почав вести курси «Основні правові системи сучасності», «Порівняльне право» та «Порівняльне державне (конституційне) право» в Інституті міжнародних відносин і розробив методичні посібники 3 цих дисциплін [18, с. 18].

У 1961 році при Академії наук УРСР у складі Сектору держави і права була створена науково-галузева група з державного права зарубіжних країн, а у 1965 році - відділ проблем міжнародно-правової діяльності УРСР і порівняльного державознавства на чолі з В.М. Корецьким. У 1969 році Сектор держави і права був перетворений на Інститут держави і права. Серед основних напрямів науково-дослідної роботи Інституту була розробка правових проблем розвитку світової соціалістичної системи та актуальних питань порівняльного державознавства [13, с. 11-12].

У 70-80-х роках XX ст. порівняльно-правові дослідження в Україні набули все більшої популярності $[10$, с. $9 ; 24$, с. $13 ; 37$, с. 13]. Унаслідок цього було видано чимало праць у сфері компаративістики, зокрема монографії Г.В. Александренка «Буржуазний федералізм» (1962 р.), O.I. Ганусець, Я.Г. Плясуна, В.Ф. Пеньківського «Нариси державно-політичного розвитку африканських країн. Алжир, Малі, Гвінея, Камерун» (1967р.), В.М. Шаповала «Правове становище профспілок в окремих країнах Африки» (1973 р.), "Розвиток законодавства про працю і соціальне забезпечення в країнах Східної Африки» (1974 р.), «Тенденції розвитку трудового законодавства в країнах Східної Африки» (1974р.), В.Н. Денисова «Системи права країн, що розвиваються» (1978 р.), Г.І. Чангулі «Конституційні принципи кримінального судочинства зарубіжних соціалістичних держав» (1981 р.), Ю.І. Нипорка «Конституційні взаємовідносини Президента і Конгресу США в галузі зовнішньої політики» (1979р.), В.М. Селіванова «Державний механізм управління США в умовах поглиблення загальної кризи капіталізму» 
(1983 р.), В.К. Забігайла «Конституція США: гасла і реальний правопорядок» (1987 р.) тощо [18, с. 18].

У 1977 році відділ проблем міжнародно-правової діяльності УРСР та порівняльного державознавства при Академії наук УРСР був перейменований на відділ міжнародного права і порівняльного правознавства. У 1984 році у складі відділу теорії держави і права був створений сектор проблем контрпропагандистської роботи у галузі держави і права, який згодом був перетворений на сектор теорії права і порівняльного правознавства. У 1988 році дослідження у сфері порівняльного правознавства були передані до компетенції відділу проблем організації громадянського суспільства, держави і теорії права, при якому продовжували існувати сектор теорії права і сектор порівняльного правознавства, які на початку 90 -х років були ліквідовані.

у 90-х роках (після проголошення незалежності) правознавство в Україні починає розвиватися прискореними темпами. До факторів, які сприяли розвитку порівняльно-правових ідей, можна віднести запозичення наукових здобутків західноєвропейських вчених, потребу в державному будівництві, взаємодію національного і міжнародного права, а також вступ України до Ради Європи, Організації з Безпеки та Співробітництва в Європі, Світової Організації Торгівлі, державну політику в сфері адаптації права України до права Європейського Союзу тощо [18, с. 18].

Кінець XX - початок XXI ст. розпочав новий етап вітчизняної компаративістики та їі утвердження як самостійної науки. На юридичних факультетах вищих навчальних закладів України створюються спеціалізовані кафедри порівняльного правознавства та впроваджуються курси порівняльного права. Важливий внесок у розвиток вітчизняної компаративістики в цей час зробили такі вітчизняні науковці, як В.Н. Денисов, В.К Забігайло, О.Є. Лисенко, В.П. Мартиненко, М.I. Марченко, В.В. Оксамитний, В.П. Казимирчук, О.В. Зайчук, Л.О. Корчевна, Л.А. Луць, Н.М. Оніщенко, П.М. Рабінович, О.Ф. Скакун, 0.О. Мережко, В.В. Молдован, В.М. Шаповал, М.М. Страхов, Ю.М. Оборотов, Х.Н. Бехруз і багато інших [18, с. 19].

Праця відомого вітчизняного дослідника права B.Н. Денисова «До критики буржуазних концепцій порівняльного правознавства» (1985 р.) стала першим в українській юридичній науці комплексним дослідженням еволюції порівняльного правознавства. На думку вченого, порівняльне право здатне не просто поглибити теоретичні знання про право та правові системи світу, а й створити умови для мирного співробітництва держав з різним суспільним ладом і сприяти зменшенню напруженості у міжнародних стосунках [7, с. 237 , 253-256].
Не менш важливим для розвитку української компаративістики стало відродження наприкінці XX ст. філософсько-правового підходу до порівняльногоправознавства. Яскравим представником даного напряму можна вважати П.Ф. Мартиненка - компаративіста, автора перших вітчизняних праць з філософії порівняльного правознавства. Так, у своєму дослідженні «Цілісність світу та порівняльне правознавство» (1990р.) науковець визначив порівняльне правознавство як самостійну науку, що вивчає зв'язки і взаємодії різних правових систем, принципи їх типологічної спільності, елементи схожості та відмінності, елементи спільного i національно-специфічного, їх внутрішні типологічні тенденції [22, с. 30]. До основних завдань компаративістики вчений відносить вивчення об'єктивних зв'язків національних правових систем і розробку моделі типових правових систем сучасності, виокремлення і узагальнення основних форм міжсистемних правових впливів та взаємодій, систематизацію методології порівняльно-типологічного підходу у праві. На думку П.Ф. Мартиненка, предметом компаративістики є сукупне наукове знання про об'єктивне порівняльне право як багатосистемне існуюче право, юридичні норми, які виражають міжсистемні та транссистемні зв'язки, впливи і взаємодії у праві. Об'єктом компаративістики, на його думку, є загальна правова картина світу [22, с. 31].

У XXI ст. вітчизняна компаративістика продовжує активно розвиватись, а порівняльно-правові дослідження набувають все більшої популярності. Нині в Україні існує багато організацій i установ, що займаються дослідженнями у сфері порівняльного правознавства. На юридичних факультетах багатьох вищих навчальних закладів функціонують кафедри порівняльного правознавства, видається багато спеціалізованих періодичних видань (наукових журналів, збірників, вісників, інформаційних бюлетенів) порівняльного права [18, с. 17].

У 1997 році згідно з домовленістю між Україною та Європейською Комісією був створений Українсько-європейський дорадчий центр з питань законодавства, основним призначенням якого стало надання консультативної допомоги Верховній Раді України, Адміністрації Президента України і Кабінету Міністрів в досягненні повномасштабної імплементації Угоди про партнерство та співробітництво між Україною та ЄС 1994 р., зокрема і в питаннях зближення національного законодавства України і права $\mathrm{CC}$, а також експертно-консультативна підтримка процесу вступу України до СОТ. Центр діяв до 2009 року і видав «Методичний посібник 3 питань імплементації Угоди про партнерство та співробітництво між Україною та ЄС (1994р.)», "Матриці показників ефективності наближення законодавства Украї- 
ни до законодавства ЄС», методики тлумачення законодавства України в світлі правових принципів ЄС, проєкт моделі порівняльної оцінки процесу адаптації законодавства України до права ЄС та науково-практичні журнали «Тенденції української економіки» (1997-2000рр.), «Українсько-європейський журнал міжнародного та порівняльного права» (2000-2002 рр.), «Український правовий часопис» (2002-2004 pp.), англомовну версію журналу "Ukrainian Law Review", щомісячний «Інформаційний бюлетень Українсько-європейського консультативного центру 3 питань законодавства», «Інформаційний вісник» тощо [18, с. 17].

У 1998 році при Міністерстві юстиції України був створений Центр порівняльного права, а в 2003 році на його основі - Центр європейського та порівняльного права. До основних завдань Центру належало здійснення порівняльно-правового аналізу міжнародного, європейського, зарубіжного права і права України, розробка та вдосконалення методології адаптації правової системи України до законодавства ЄС, її організаційно-методичне, інформаційне, технічне забезпечення. В ході діяльності Центром були видані книги «Регулювання сфрери фінансових послуг в праві ЄС та перспективи адаптації законодавства України» (2002р.), «Податкові аспекти права COT та acquis EC. Opiєнтири податкової реформи в Україні» (2004р.), «Боротьба 3 відмиванням грошей: комплексний порівняльно-правовий аналіз відповідності законодавства України acquis ЄC в сфері боротьби та запобігання легалізації доходів, отриманих злочинним шляхом» $(2004$ р.) [18, с. 17].

На початку 2005 року Центр європейського та порівняльного права був ліквідований, а замість нього був створений Державний департамент з питань адаптації законодавства при Міністерстві юстиції України. Основними завданнями департаменту було науково-експертне, аналітичне, інформаційне і методологічне забезпечення адаптації законодавства України до законодавства ЄС, координація співробітництва між Україною та ЄС у сфері адаптації законодавства України до законодавства ЄC і у сфері юстиції та внутрішніх справ [3, с. 144].

Важливе значення для розвитку вітчизняної компаративістики мають порівняльно-правові дослідження Національної академії наук та Академії правових наук. У 1998 році в Інституті держави і права ім. В.М. Корецького НАН України був відновлений відділ міжнародного права та порівняльного правознавства. Були опубліковані праці Н.Р. Малишевої «Гармонізація екологічного законодавства у Свропі» (1996 р.), «Реалізація міжнародних норм у внутрішньо-державному праві» за ред. В.Н. Денисова (1992 р.), В.В. Оксамитного, Ю.Ю. Леонова, В.В. Колесника «Еволюція су- часних буржуазних держави та права» (1991р.), B.I. Євінтова «Зарубіжний досвід: французький посередник з прав людини» (1995 р.), О.В. Зайчука, Н.М. Оніщенка, В.С. Журавського, О.Л. Копиленка «Правові системи сучасності» (2003р.) та інших українських компаративістів. У 2001 році при Інституті держави і права ім. В.М. Корецького був створений Центр порівняльного правознавства та європейського права, директором якого був призначений O.В. Кресін. Головна мета Центру - це сприяння розвитку теоретичних і прикладних досліджень у галузі порівняльного правознавства та у дослідженні європейського права, здійснення наукового забезпечення законопроєктних робіт, розробка пропозицій і рекомендацій з приводу адаптації національного законодавства України до міжнародного і європейського права [18, с. $17-18 ; 23$, с. 79].

Починаючи з 2002 року, Інститутом держави і права ім. В.М. Корецького була видана серія наукових видань «Енциклопедія порівняльного правознавства» у п'яти книгах: «Порівняльне правознавство. Порівняльна політологія: систематичний бібліографічний покажчик», «Порівняльне правознавство: вітчизняні та зарубіжні спеціалізовані центри дослідження і викладання. Довідник», «Видатні компаративісти: творчий шлях, ідеї, праці», «Порівняльне правознавство у системі юридичних наук: проблеми методології: монографія», «Порівняльне правознавство: антологія української компаративістики XIX-XX століть», а з 2007 року - серія науково-методичних видань «Академія порівняльного правознавства», де було опубліковано понад 28 матеріалів відкритих лекцій видатних українських компаративістів [18, с. 17-18].

На юридичному факультеті Київського національного університету імені Тараса Шевченка активно здійснюються порівняльно-правові дослідження та викладається навчальна дисципліна «Історія держави і права зарубіжних країн». 32011 року на кафедрі історії права та держави для студентів-магістрів існує окрема спеціалізація «Порівняльне правознавство», де викладаються курси «Порівняльне правознавство», «Еволюція державно-політичного ладу європейських країн», «Східна традиція права», «Історія римського права», «Історія світового конституціоналізму», «Релігійно-традиційна правова сім'я», «Історія європейської юстиції», «Змішане порівняльне право», «Становлення і розвиток романо-германської правової сім'ї», «Становлення і розвиток сім’ї загального права».

3 огляду на зазначене можна дійти висновку, що вітчизняна юридична компаративістика пройшла складний і тривалий шлях становлення від методу юридичної науки до самостійної галузі знань. На основі аналізу праць вітчизняних ком- 
паративістів можна виокремити шість основних етапів еволюції порівняльного правознавства в Україні.

Перший етап (X - перша половина XVIII ст.) характеризується зародженням порівняльно-правових ідей на українських землях. Результатом перших досліджень зарубіжного права стала рецепція римського, юдейського, візантійського і болгарського права на Русі. За Литовсько-Руської доби відбулася рецепція західноєвропейського феодального права, наслідком якої стала поява в українських містах магдебурзького права.

Другий етап (перша половина XVIII - початок XIX ст.) характеризується тим, що порівняльне правознавство використовується як практична діяльність 3 порівняння норм права наднаціонального та регіонального рівня. На основі порівняння Литовського Статуту, магдебурзького і хелмінського права, гетьманського та російського законодавства, судової і адміністративної практики, українського звичаєвого права створюються кодифіковані збірники права, що вказує на високий рівень тогочасної вітчизняної юридичної науки.

Третій етап (початок XIX - кінець XIX ст.) характеризується розвитком порівняльно-правових ідей, а також зростанням кількості та якості компаративістських досліджень, оформленням порівняльного правознавства як навчальної дисципліни. Важливий внесок у розвиток вітчизняної компаративістики в цей період зробили представники київської історичної школи права та її послідовники. Під порівняльним правознавством розуміють метод юридичної науки.

Четвертий етап (кінець XIX - початок XX ст.) характеризується інституціоналізацією порівняльно-правових досліджень. У вищих закладах освіти створюються кафедри порівняльного права. Порівняльне правознавство починає оформлюватися у самостійну юридичну науку.

П'ятий етап (перша половина XX - друга половина XX ст.) характеризується обмеженням розвитку порівняльного правознавства в Україні в умовах ідеологічного диктату, політикою самоізоляції, відсутністю кваліфікованих юридичних кадрів, а також хибністю методологічних поглядів деяких науковців з приводу недоцільності порівняння буржуазного та соціалістичного права. Більшість порівняльно-правових досліджень в цей період була замінена на критику буржуазного права.

Шостий етап (кінець XX - початок XXI ст.) характеризується відродженням філософсько-правового підходу до порівняльного правознавства та популяризацією порівняльно-правових досліджень. В Україні створюються спеціалізовані організації та установи, які займаються дослідженнями зарубіжного права. На юридичних факультетах багатьох вищих закладів освіти функціонують кафедри порівняльного правознавства, видається багато спеціалізованих періодичних видань (наукових журналів, збірників, вісників, інформаційних бюлетенів). Юридична компаративістика утверджується як самостійна наука.

\section{Jimepamypa}

1. Бондарук T.I. Основоположники Київської історико-юридичної школи М.Ф. Владимирський-Буданов і Ф.І. Леонтович. Київ, 1995. 25 с.

2. Бондарук T.I. Західноруське право: дослідження і дослідники (Київська історико-юридична школа). Київ : Ін-т держави і права ім. В.М. Корецького НАН України. 2000. 160 с.

3. Видатні компаративісти: творчий шлях, ідеї, праці / О. В. Кресін (кер. авт. кол.), В.Н. Денисов, М.А. Дамірлі та ін. Київ : Інститут держави і права ім. В.М. Корецького НАН України ; Вид-во «Логос», 2007. Серія наукових видань «Енциклопедія порівняльного правознавства». Вип. 4.144 с.

4. Войно-Данчишина О.Л. Высшее юридическое образование в украинских губерниях Российской империи в первой половине XIX века. Юридична наука та освіта: історія, сучасність, перспективи : матеріали IX історико-правової конференції / ред. кол. І.Б.Усенко (голова) та ін. Київ, 2004. С. 89.

5. Гриценко I.С. М.Д. Іванішев - засновник історико-правової школи університету св. Володимира. Вicник Київського національного університету іл. Тараса Шевченка. Серія «Юридичні науки». Київ : Київ. ун-т, 2000. Вип. 40. С. 13-17.

6. Графский В.Г. Право и мораль в истории: проблемы ценностного подхода. Государство и право. Москва : Наука, 1998. № 8. С. 114-119.

7. Денисов В.Н. К критике буржуазных концепций сравнительного правоведения. Порівняльне правознавство: антологія української компаративістики XIX - XX століть / за ред. О.В. Кресіна ; упоряд. : О.В. Кресін (кер. кол.), К.О. Черниченко, О.В. Ткаченко. Київ, 2008. 256 с.

8. Емельянова И.А. Всеобщая история права в русском дореволюционном правоведении (XIX век). Ч. 1 / науч. ред. Лазарев В.В. Казань : Изд-во Казан. ун-та, 1981. 159 с.

9. Иванишев Н. О плате за убийство в древнем русском и других славянских законодательствах в сравнении с германской вирой. Киев : Университетская типография, $1840.112 \mathrm{c}$.

10. Иванов В.В. Соотношение истории и современности как методологическая проблема. Москва : Наука, 1973. 288 с.

11. Збаржевецький О.Л. Історія викладання римського права в Київському університеті святого Володимира (1834-1919). Вісник Київського національного університету ілені Тараса Шевченка. Серія «Iсторія». 2006. № 87-88. С. 77-80.

12. Історія Академії наук України. 1918-1923: документи і матеріали / АН України, Інститут української археографії, Центральна наукова бібліотека ім. B.I. Вернадського, Інститут архівознавства, Інститут рукопису ; упоряд. В.Г. Шмельов та ін. ; відп. ред. П.С. Сохань. Київ : Наукова думка, 1993. 571 с.

13. Інститут держави і права iм. В.М. Корецького НАН України. Наукові досягнення за 50 років (19491999) / Ю.С. Шемшученко та ін. ; відп. ред. Ю.С. Шемшученко ; Нац. акад. наук України. Київ : Ін Юре, $1999.345 \mathrm{c}$.

14. Ковалевский M.M. Историко-сравнительный метод в юриспруденции и приемы изучения истории права. Москва, 1880.73 с. 
15. Ковалевский M.M. Социология. Сочинения в двух томах. Санкт-Петербург : Изд-во АЛЕТЕЙЯ, 1997. T. I. 288 c.

16. Ковальчук О.М. Історико-правовий напрям на юридичному факультеті Київського університету (середина XIX - початок XX ст.) Проблеми правознавства. 1991. Вип. 52. С. 29-30.

17. Косарев А.И. Об использовании сравнительного метода в историко-правовом исследовании. Советское государство и право. 1965. № 3. С. 78.

18. Кресін О.В. Порівняльне правознавство: вітчизняні та зарубіжні спеціалізовані центри дослідження і викладання : довідник / за ред. В.Н. Денисова. Київ : Інститут держави і права ім. В.М. Корецького НАН України, 2005. 192 с.

19. Лафитский В.И. Сравнительное правоведение в образах права. Том 1. Москва : Статут, 2010. 429 с.

20. Леонтович Ф.И. История русского права: университетский курс. Выпуск первый : Введение. Сочинение заслуженного профессора Ф.И. Леонтовича. Одесса : Типография Штаба Одесского Военного Округа, $1892.80 \mathrm{c}$.

21. Леонтович Ф.И. Указатель источников и исследований по истории славянских законодательств. Журнал Министерства народного просвещения. 1867. № 8. C. 365-413.

22. Мартыненко П.Ф. Целостность мира и сравнительное правоведение. Идеи мира и сотрудничества в современном международном праве : сб. статей. Киев : Научная мысль, 1990. С. 29-30.

23. Малько А.В., Саломатин А.Ю. Сравнительное правоведение : краткий учебник. Методические рекомендации. Москва : НОРМА, 2008. 352 с.

24. Масленников М.М. Методологическое значение сравнения в научном познании : моногр. Воронеж : Изд-во Воронеж. ун-та, $1968.58 \mathrm{c}$.

25. Мирное сосуществование : дипломатический словарь: в трех томах. Изд.4-е. / редкол. А.А. Громыко и др. Т. II: К - P. 1764 с.

26. Нелін O.I. Інститут нотаріату в Україні: від минувшини до сьогодення : монографія. Київ : Видавничо-поліграфічний центр «Київський університет», 2013. 130 c.

27. Очерки по истории юридических научных учреждений в СССР / отв. ред. В.М. Курицын, А.Ф. Шебанов. Москва : Наука. 1976. 238 с.

28. Порівняльне правознавство : курс лекцій Л.В. Голяк, А.С. Мацко, О.В. Тюріна. Київ : МАУП, 2004. $200 \mathrm{c}$.

29. Лисенко О.М. Порівняльне правознавство як наука та його місце в системі юридичних наук : автоpeф. дис. ... канд. юрид. наук. 2001. 19 с.

30. Ренненкампф Н.К. О современной обработке сравнительного правоведения. Порівняльне правоз навство : антологія української компаративістики XIX-XX століть / за ред. О.В. Кресіна ; упоряд.: О.В. Кресін (кер. кол.), К.О. Черниченко, О.В. Ткаченко. Київ, 2008. С. 90-96.

31. Скакун О.Ф. Теорія права і держави : підручник. 2-ге видання. Київ : Алерта ; ЦУЛ, 2011. 520 с.

32. Скрипилев Е.А. Историко-сравнительный метод в правоведении России второй половины XIX начала XX в. Методология историко-правовых исс ледований / отв. ред. В.Е. Гулиев. Москва : Институт государства и права АН СССР, $1980.30 \mathrm{c}$.

33. Совенко Б.В. Становлення і розвиток православного канонічного права в Україні : автореф. дис. ... канд. юрид. наук : 12.00.01 «Теорія та історія держави і права; історія політичних і правових вчень» ; Національний педагогічний університет імені М.П. Драгоманова України. Київ, 2011. 19 с.

34. Сохань П.С., Ульяновський В.I., Кіржаєв С.М. М.С. Грушевський і Academia: ідея, змагання, діяльність. Київ, 1993. С. 90-94.

35. Тарановский Ф.В. Сравнительно-исторический метод и сравнительное правоведение. Порівняльне правознавство : антологія української компаративістики XIX - XX століть / за ред. О.В. Кресіна ; упоряд.: О.В. Кресін (кер. кол.), К.О. Черниченко, О.В. Ткаченко. Київ, 2008. С. 182-195.

36. Терлюк І.Я. Історія українського права від найдавніших часів до XVIII століття : навч. посіб. з істор. д-ви і права України. Львів, 2003. 156 с.

37. Халфина Р.О. Значение историко-правовых исследований для теории права. Методология историко-правовых исследований / отв. ред. В.Е. Гулиев. Москва : Ин-т гос. и права Академии наук СССР, 1980. C. $29-40$

\section{Анотація}

Карпічков В. О. Еволюція юридичної компаративістики в Україні. - Стаття.

У статті досліджується процес еволюції юридичної компаративістики як самостійної науки на теренах Української Держави в різні періоди їі розвитку. На основі аналізу праць вітчизняних науковців виокремлено шість основних етапів еволюції порівняльного правознавства в Україні.

Перший етап (X - перша половина XVIII ст.) характеризується зародженням порівняльно-правових ідей на українських землях і рецепцією зарубіжного права.

Другий етап (перша половина XVIII - початок XIX ст.) характеризується використанням порівняльного правознавства як практичної діяльності з порівняння норм права наднаціонального та регіонального рівнів під час кодифікації українського права.

Третій етап (початок XIX - кінець XIX ст.) характеризується зростанням кількості та якості компаративістських досліджень і оформленням порівняльного правознавства як навчальної дисципліни.

Четвертий етап (кінець XIX - початок XX ст.) характеризується інституціоналізацією порівняльно-правових досліджень, створенням кафедр порівняльного права, початком становлення порівняльного правознавства як самостійної науки.

П'ятий етап (перша половина XX - друга половина $\mathrm{XX}$ ст.) характеризується обмеженням розвитку порівняльного правознавства в Україні в умовах ідеологічного диктату, політикою самоізоляції, відсутністю кваліфікованих юридичних кадрів, а також хибністю методологічних поглядів деяких науковців 3 приводу недоцільності порівняння буржуазного та соціалістичного права.

Шостий етап (кінець XX - початок XXI ст.) характеризується відродженням філософсько-правового підходу до порівняльного правознавства і популяризацією порівняльно-правових досліджень в Україні, створенням спеціалізованих організацій та установ, які займаються дослідженням зарубіжного права, утвердженням юридичної компаративістики як самостійної науки.

Ключові слова: українська компаративістика, юридична компаративістика, порівняльне право, порівняльне правознавство, юридична наука. 


\section{Summary}

Karpichkov V. O. Evolution of legal comparative science in Ukraine. - Article.

The article explores the process of evolution of legal comparative science as an independent science in the territory of the Ukrainian state in different periods of its development. Based on the analysis of the works of domestic scientists, six main stages of the evolution of comparative law in Ukraine have been identified.

The first stage (X - the first half of the XVIII century) is characterized by the emergence of comparative legal ideas in Ukrainian lands and the reception of foreign law.

The second stage (the first half of the XVIII century the beginning of the XIX century) is characterized by the use of comparative law as a practical activity for comparing the norms of law of the supranational and regional levels in the codification of Ukrainian law.

The third stage (the beginning of the XIX - the end of the XIX century) is characterized by an increase in the quantity and quality of comparative studies and the legalization of comparative law as a discipline.
The fourth stage (the end of the XIX - the beginning of the XX century) is characterized by institutionalization of comparative-legal researches, creation of departments of comparative law, beginning of formation of comparative law as independent science.

The fifth stage (first half of the XX - second half of the $\mathrm{XX}$ century) is characterized by the restriction of the development of comparative jurisprudence in Ukraine by the conditions of ideological dictation, the policy of self-isolation, the lack of qualified legal staff, as well as the flawed methodological views of some scholars regarding the inappropriate comparison of bourgeois and socialist law.

The sixth stage (the end of the XX - the beginning of the XXI centuries) is characterized by the revival of philosophical and legal approach to comparative law and popularization of comparative-legal researches in Ukraine, the creation of specialized organizations and institutions engaged in the study of foreign law, the establishment of legal comparative science as an independent.

Key words: Ukrainian comparative law science, legal comparative science, comparative law, comparative legal science, legal science. 